13 Higgins J, Green S. Cochrane Handbook for Systematic Reviews of Interventions (version 5.1.0). Cochrane Collaboration, 2011.

14 In $t^{\prime}$ Veld BA, Ruitenberg A, Hofman A, Launer LJ, van Duijn CM, Stijnen T, et al. Nonsteroidal antiinflammatory drugs and the risk of Alzheimer's disease. N Engl J Med 2001; 345: 1515-21.

15 Breitner JC, Baker LD, Montine TJ, Meinert CL, Lyketsos CG, Ashe KH, et al. Extended results of the Alzheimer's disease anti-inflammatory prevention trial. Alzheimers Dement 2011; 7: 402-11.

16 Street JS, Clark WS, Gannon KS, Cummings JL, Bymaster FP, Tamura RN, et al Olanzapine treatment of psychotic and behavioral symptoms in patients with Alzheimer disease in nursing care facilities: a double-blind, randomized, placebo-controlled trial. The HGEU Study Group. Arch Gen Psychiatry 2000; 57: $968-76$.

17 De Deyn PP, Carrasco MM, Deberdt W, Jeandel C, Hay DP, Feldman PD, et al. Olanzapine versus placebo in the treatment of psychosis with or without associated behavioral disturbances in patients with Alzheimer's disease. Int J Geriatr Psychiatry 2004; 19: 115-26.

18 Tohen M, Jacobs TG, Grundy SL, McElroy SL, Banov MC, Janicak PG, et al. Efficacy of olanzapine in acute bipolar mania: a double-blind, placebocontrolled study. The Olanzipine HGGW Study Group. Arch Gen Psychiatry 2000; 57: 841-9.

19 McIntyre RS, Cohen M, Zhao J, Alphs L, Macek TA, Panagides J. A 3-week, randomized, placebo-controlled trial of asenapine in the treatment of acute mania in bipolar mania and mixed states. Bipolar Disord 2009; 11: 673-86.
20 Marshall M, Lockwood A, Bradley C, Adams C, Joy C, Fenton M. Unpublished rating scales: a major source of bias in randomised controlled trials of treatments for schizophrenia. Br J Psychiatry 2000; 176: 249-52.

21 Wood L, Egger M, Gluud LL, Schulz KF, Juni P, Altman DG, et al. Empirical evidence of bias in treatment effect estimates in controlled trials with different interventions and outcomes: meta-epidemiological study. BMJ 2008; 336: $601-5$

22 Savovic J, Jones HE, Altman DG, Harris RJ, Juni P, Pildal J, et al. Influence of reported study design characteristics on intervention effect estimates from randomized, controlled trials. Ann Intern Med 2012; 157: 429-38.

23 Cumming G. Replication and $p$ intervals: $p$ values predict the future only vaguely, but confidence intervals do much better. Perspect Psychol Sci 2008; 3: $286-300$.

24 Ioannidis JP. Why most discovered true associations are inflated. Epidemiology 2008; 19: 640-8.

25 Leucht S, Hierl S, Kissling W, Dold M, Davis JM. Putting the efficacy of psychiatric and general medicine medication into perspective: review of meta-analyses. Br J Psychiatry 2012; 200: 97-106.

26 Schulz KF, Chalmers I, Hayes RJ, Altman DG. Empirical evidence of bias. Dimensions of methodological quality associated with estimates of treatment effects in controlled trials. JAMA 1995; 273: 408-12.

\title{
psychiatry in history
}

\section{Could Marcus Aurelius be the missing link in the insanity defence?}

\section{John H. M. Crichton}

It is accepted that Modestinus (C. 320 CE) is the earliest source of the insanity defence, but Walker posed the question, '[W]here did Modestinus get his doctrine and his reasoning?' (Annals of the American Academy of Political and Social Science 1985). The surviving writing of Modestinus reveals a clue as to its origin:

'Truly, if anyone kills a parent in a fit of madness, he shall not be punished, as the deified brothers wrote in a rescript in the case of a man who had killed his mother in a fit of madness; for it was enough for him to be punished by the madness itself, and he must be guarded the more carefully, or even confined with chains' (The Digest of Justinian, University of Pennsylvania Press 1985).

It is possible this refers to a case discussed in a letter from joint emperors Marcus Aurelius and Commodus 177-180 CE:

'If you have ascertained that Aelius Priscus is so insane that he is permanently mad and thus he was incapable of reasoning when he killed his mother, and did not kill her with the pretense of being mad, you need not concern yourself with the question how he should be punished, as insanity itself is punishment enough. At the same time he should be kept in close custody, and ... even kept in chains. This need not be done by way of punishment so much for his own and his neighbours' security... But since we learn ... that he is in the hands of friends .... your proper course is to summon those in charge of him at the time and enquire how they were so remiss, and then to pronounce on each case separately, according to whether there is any excuse or aggravation for their negligence. The object of keepers for the insane is not merely to stop them from harming themselves, but from destroying others, and if this happens, there is some justification for casting the blame for it on those who were somewhat negligent in their duties (A. Birley, Marcus Aurelius, Eyre and Spottiswoode 1966).

The advice in the Aelius Priscus case is similar to Plato's writings both in terms of the reduced responsibility of the mentally unwell homicide perpetrator and also the vicarious responsibility of the 'keepers for the insane' (The Laws). Plato was also a major influence on Marcus Aurelius' philosophical writings. This surviving letter provides a possible link between Plato and English common law. 